\title{
PENERAPAN PEMBUKTIAN SEDERHANA DALAM KEPAILITAN MENURUT UNDANG-UNDANG NO 37 TAHUN 2004 TENTANG KEPAILITAN DAN PKPU (STUDI KASUS: PUTUSAN NOMOR: 04/PDT.SUS.PAILIT/2015/PN.NIAGA.JKT.PST)"
}

\author{
Rafael Angelo Dias \\ (Mahasiswa Program S1 Fakultas Hukum Universitas Tarumanagara) \\ (E-mail: rafaelangelodiaz @gmail.com) \\ Dr. Suyud Margono, S.H., MHum., FCIArb \\ (Corresponding Author) \\ (Dosen Fakultas Hukum Universitas Tarumanagara. Meraih Sarjana Hukum pada Fakultas Hukum \\ Universitas Atmajay, Magister Hukum pada Fakultas Hukum Universitas Tarumanagara, Doktor (Dr.) \\ pada Fakultas Hukum Universitas Parahyangan.) \\ (E-mail: suyudmargono@gmail.com)
}

\begin{abstract}
In submitting a bankruptcy application, the applicant must submit evidence to prove the existence of a debt. The specialty of proof in the law of bitterness is the existence of simple proof, according to the juridical requirements as referred to in Article 8 paragraph (4) according to the juridical requirements as referred to in article 2 paragraph (1) of the bankruptcy law. This simple proof can also cause problems. One concrete form of the problem that arises in this simple verification in practice is the decision of the Commercial Court at the Central Jakarta District Court with the decision number: 04 / Pdt-Sus.Pailit / 2015 / PN.Niaga / JKT.PST between the Service Authority Commissioner Board and PT Asuransi Jiwa Bumi Asih Jaya. The problem is how to apply simple evidence in the case. This writing uses normative legal research methods which are based on primary data and secondary data which are analyzed descriptively with conceptual and legislative approaches. Based on the analysis according to Article 8 paragraph (4) in conjunction with Article 2 paragraph (1) UUKPKPU, it can be stated that the debt of PT Asuransi Jiwa Bumi Asih Jaya has been proven in a simple manner, but the Judges in the decision rejected the application on the grounds that the debt proof was not simple. 8 paragraph (4) UUKPKPU.
\end{abstract}

. Keywords: Keyword: Bankruptcy, Simple Proof, Evidence 


\section{PENDAHULUAN}

\section{Latar Belakang}

Dalam dunia bisnis, kegiatan-kegiatan usaha tidak setiap saat berjalan lancar. Ada kalanya situasi perekonomian suatu negara sedang buruk ataupun keadaan keuangan perusahaan itu sendiri yang sedang buruk karena pendapatannya menurun atau semakin tingginya biaya produksi sehingga perusahaan tidak mempunyai modal yang cukup untuk mampu membayar utangutangnya. Setiap perusahaan pasti memerlukan uang sebagai dana yang digunakan untuk menjalankan kegiatan usahanya. Namun kadang kala perusahaan terpaksa harus mengambil pinjaman kepada pihak lain, seperti bank karena kekurangan dana, baik untuk menjalankan kegiatan operasional seharihari maupun untuk membayar utang-utangnya kepada kreditor-kreditornya. Pihak pemberi pinjaman disebut kreditor yaitu yang diutangi, sementara debitor yaitu yang berutang adakah merupakan yang mendapatkan piinjaman. Pinjaman yang diberikan tersebut diserahkan oleh kreditor untuk debitor oleh sebab kepercayaan kreditor terhadap debitor mengenai kemampuannya dalam melunasi kembali utang beserta bunganya di waktu yang disepakati kepada kreditor. Namun pada kenyataannya, tidak sedikit debitor yang mempunyai hutang dan tak sanggup melunasi kembali pinjamannya, oleh karena ketidakmampuannya dalam memenuhi kewajibannya tepat waktu. Saat terjadi hal seperti ini, diperlukan rujukan terhadap peraturan umum yang bersangkutan dengan larangan dalam kitab hukum perdata. Larangan tersebut secara umumnya diatur dalam KUH Perdata. Satu pedoman yang lumayan penting mengenai keperdataan adalah peretujuan yang sudah disusun secara jelas melibatkan seluruh piihak (Pasal 1338 KUH Perdata). Mengikat berarti kedua belah pihak mempunyai hak dan kewajiban. Karena itu jika semua yang sudah disepakati tak mampu dipenuhi oleh seluruh pihak, akibatnya konsekuensi secara hukum dapat dilimpahkan kepada pihak yang lalai dalam melaksanakan kewajiibannya. Maka hak untuk 
menagih menjadi diberikan kepada pihak yang berhasil dan sudah melaksanakan apa yang menjadi kewajibannya.

Saat Debitur gagal membayarkan utangnya, kreditur mempunyai hak untuk membuat aset milik debitur menjadi jamiinan untuk para berpiutang. Dalam membagi rata aset milik si berutang untuk memenuhi kewajibannya, aset debitur tersebut akan disiita besar-besaran. Menurut pakar-pakar huikum pondasi Hukum Kepailitan jelas dapat dilihat dalam Pasal 1131 serta 1132 KUH Perdata.

Kepailiitan merupakan aktivitas penyitaan secara umum terhadap seluruh aset kepemilikan pihak beruttang dalam rangka melunasi kewajibannya. Menurut Henrry Campbel Bllack pailit merupakan kondiisi atau situasii saat suatu pihak tidak mampu lagi melunasi kewajibannya. ${ }^{1}$

Ketika definisi kepailitan disambungkan kepada ketidakbisaan dalam hal melunasi utang kepada para berpiutang atas kewajibannya yanng sudah harus dibayarkan, ketidakbisaan itu semestinya diikuti aksi konkrit dalam menyatakan permohonan, baiik debitur lakukan tanpa tekanan apa pun, ataupun jika kreditur yang mengajukan permohonan, sebuah permintaan bangkrut untuk pengadiilan.

Undang-undang mengendai kepailitan merupakan satu bentuk usaha hukum yang kemudian merupakan pilar dalam menyelesaikan hutang yang dekat hubungannya pada kepailitan bidang bisnis adalah peraturan tentang kepailitan, dimana di antaranya adalah peraturan tentang penundaan kewajiban pembayaran utang. Walaupun sebelumnya sudah disusun Undang-Undang Nomor 4 Tahun 1998, namun masih dirasa kurang dalam memenuhi permasalahan kepailitan yang terjadi di dalam masyarakat. Maka disusunlah Undang-undang yang baru pada tahun 2004 yaitu UndangUndang Nomorr 37 Tahun 2004 mengenai pailit

\footnotetext{
${ }^{1}$ Henry Campbell Black, Black's Law of Dictionary, (St. Paul Minnesota: West Publishing Co., 1979), hal. 134.
} 
serta penundaaan kewajiiban pelunasan utang dimana Undang-Undang tersebut merupakan pembaharuan atas UndangUndang Nomorr 4 Tahun 1998.

Persoalan penyelesaian hutang piutang perusahaan diharapkan dapat dipecahkan melalui adanya pembaharuan atas UndangUndang Nomor 4 Tahun 1998. Namun nyatanya, sampai detik ini masih banyak persoalan yang terjadi di dalam dunia kepailitan, salah satunya adalah dalam hal pembuktian dalam kepailitan. Tahap pembuktian mempunyai fungsi yang penting di dalam menyelesaikan masalah di pengadilan, baik itu perkara pidana khusus, pidana umum, perdata umum, perdata khusus, maupun tata usaha negara dimana di sini adalah salah satu permasalahan pailit dan permasalahan lain yang diamati dan diadiili dalam pengadiilan.

Dalam permasalahan di bidang perdata biasanya, penyelidikan atas adanya relasi dalam hukum yang merupakan pondasi gugatan apakah nyata atau tak nyata, adalah salah satu tugas yang diberikan kepada hakim. ${ }^{2}$ Relasi huikum ini wajib dibuktiikan para Pembuat gugatan pada saat Pembuat gugatan menghendaki dikabulkannya gugatannya. Ketidakberhasilan Pembuat gugatan dalam hal pembuktian daliil-daliil yang merupakan pondasi gugatan, demikian menjadi beresiko bahwa gugatan tersebut tidak diterima majelis hakiim yang mengamati dan mengadiili permasalahan itu. ${ }^{3}$

Pembuktian sederhana adalah sebuah hall menonjol serta mencolok terlebih untuk hal pembuktiian pada permasalahan pailit disandingkan kepada permasalahan perdata secara umum. Supaya kepailitan menjadi terpenuhi, yaiitu pengabulan sitaan uimum terhadap semua kekayaan si berutang yang menjamin pembayaran utang piutangnya pada si berpiutang, sehingga peraturan kepailitan

\footnotetext{
${ }^{2}$ Retnowulan Sutantio dan Iskandar Oeripkartawinata, Hukum Acara Perdata Dalam Teori dan Praktek, (Bandung: Mandar Maju, 2009), hal. 58.

${ }^{3}$ Ibid.
} 
menyatakan pasal pembuktian sederhana wajib terpenuhi saat memeriksa permasalahan kepailiitan.

Pasal 1 Ayat (6) UndangUndang Nomor 37 Tahuin 2004 mengenai kepaiilitan dan kewajiban pelunasan utang yang tertunda yang disebutkan jika hutang merupakan "Kewajiiban yanng ditunjukkan yang berupa nominal uang, baiik Rupiah ataupun mata uang asiing, langsung ataupun mucul dii masa depan atau muncul oleh sebab adanya janji atau perundangan dan yang harus dilaksanakan para debitor dan jika tidak dlakukan maka memberi kewenangan untuk si berpiutang dalam mengambil pemenuhan dari aset-aset milik si berutang."

Sesuai penjelasan tersebut, kita lihat jika definisi yang sangat luas terkandung dalam Undang-Undang Nomorr 37 Tahun 2004 mengenai pailit dan kewajiiban pelunasan utang yang tertunda sebagai peraturan yang berlaku mengenai permasalahan pailit dii Indonesiia. Hal ini pada kenyataannya mengakibatkan permasalahan di perkara di pengadilan jika dihubungkan kepada pembuktiian sederrhana.

Pemikiran menjadi semakin maju terkait pembuktiian sederrhana di era Faillissementsverordeniing di antaranya pembuktiian mengenai si berutang di kondisi tidak lagi melunasi harius dijalankan dengan sedeirhana. Berarti, saat Pengadiilan meneliti permohoinan pernyattaan paiilit tak harus menyamai siistem pembuktiian sertabuktii tertentu di Huikum Acara Perdata. ${ }^{4}$

Pengaturan pembuktiian sederihana mengharuskan pembuktiian sederhana pada hall keberadaan sedikitnnya dua berpiutang serta sedikitnya sebuah uttang telah mencapai tenggat waktu. Tidak adanya definisi yang jelas dalam aplikasi pembuktiian sederihana menyebabkan semakin senjangnya

\footnotetext{
${ }^{4}$ Zainal Asikin, Hukum Kepailitan dan Penundaan Pembayaran di Indonesia, (Surabaya: Bina Ilmu, 1990), hal. 28.
} 
pendapat antarhakim untuk menerapkan definisi pembuktiian sederihana dallam penyelesaian permasalahan kepaiilitan. ${ }^{5}$

Masalah lain dapatt pula disebabkan oleh pembuktiian sederihana. Konsekuensinya adalah terlampau sederhananya dalam memenuhi permoihonan paiilit sebab yang memohonkan paiilit hannya perlu menunjukan bukti bahwa si berutang memiliki sedikitnya dua berpiutang serta paling sedikit sebuah uitang tenggat waktu serta sudah bisa ditagihkan, tidak perlu menimbang si berutang sediang pada situasi sollvent ataupun tiidak, yang berarti tak bersedia melunasi disebabkan beberapa faktor, ataupun karena benar-benar sudah tak sanggup memlunasi kewajibannya. ${ }^{6}$

Suatu wujud nyata mengenai penerapan pembuktiian sederihana ialah seperti pada puttusan Pengadiilan Niiaga di Pengadiilan Negerii Jakrta Pusatt denggan nomorr puttusan: 04/Pdt-Sus.Pailit/2015/PN.Niaga/JKT.PST yaitu pada tanggal 18 Februari 2015, Dewan Komisioner Otoritas Jasa Keuangan memintakan perrmohonan pernyataaan paiilit atas PT Asuransii Jiwa Bumii Asiih Jaya dii Pengadiilan Niiaga di Pengadiilan Negerii Jakartta.

Seiring dengan berjalannya waktu, PT Asuransi Jiwa Bumi Asih Jaya tidak berhasil menyelesaikan upaya Penundaan Kewajiban Pembayaran Utang sehingga Otoritas Jasa Keuangan mengajukan perrmohonan pernyataaan paiilit kepada PT Asuransii Jiiwa Bumii Ash Jaaya. Yang menjadi penyebab dari pengajuan permohonan pernyataan pailit tersebut ialah karena PT Asuransi Jiwa Bumi Asih Jaya tak mampu melaksanakan kewajibannya berdasarkan undangundang tentang asuransi dengan tidak memenuhi tingkat solvabilitas paling sedikit $120 \%$ serta sedikitnya duaa berpiutang serta tak melunasi paling sedikit

${ }^{5)}$ Aria Suyudi, Eryanto dan Herni Sri Nurbayanti, Kepailitan di Negeri Pailit, (Jakarta: Pusat Studi Hukum dan Kebijakan Indonesia, 2004), hal. 148.

6 ) Ali, "Hakim Karier Menilai Proses Kepailitan Terlalu Mudah", http://www.hukumonline.com/berita/baca/lt51eea824de1c3/hakim-karier-menilai-proses-kepailitanterlalu-mudah, diakses pada tanggal 20 Maret 2018 pukul 10.40 WIB. 
satuutang tenggat waktu. Kreditur adalah pemegag poliis asurnsi P T Asuransi Jiwa Bumi Asih Jaya serta uttang kepada P T Bannk Tabugan Negarra, Tbk. melalui PT Binasentra Purna.

Setelah diperiksa dengan proses rpanjang pada Pengadiilan Niiaga di Pengadilan Negeri Jakarta Pusat, Majeliis Hakiim berkesimpulan perrmohonan paiilit olleh Dewaan Komisoner ditolak karena tidak terpenuhinya unsur pembuktiian sederihana seperti diatur pada PasaI 8 ayat (4) UndangUndang Nomor37 tahun2004 mengenai Kepailitan dan Penurdaan Kewajiiban Pembayran Uttang di mana adanya uttang oleh Trrmohon Paiilit tak bisa dbuktikan sccara sederrhana sebab masih terdapat perselisihan dan sanggahan dari PT Asuransi Jiwa Bumi Asih Jaya terhadap adanya uttang tersebut dan keberadaan permasalahan tatausaha negarra diantara Otoritas Jasa Keuangan dan PT Asuransi Jiwa Bumi Asih Jaya sebagaimana menuruit Majeliis Hakiim perlu menjadi pondasi dalam memutuskan adanya uttang P T Asuransi Jiwa Bumi Asih Jaya yang didalilkan oleh Otoritas Jasa Keuangan pada perrmohonan pailitnya, sehingga perrmohonan pernyattaan pailiit aquo di tolak Majeliis Hakiim menggunakan dsaar pertiimbangan jika pasal pembuktiian sederhana tak terpenuhi.

Pemohon Pailit merasa bahwa putusan atas perkara ini tidak adil dan tidak memberikan kepastiian huikum dan manfaat huikum sebab sesuai Pemoihon Pailit, Majeliis Hakiim pemeriksa dan mengadili pcrkara hanya menimbang adanya perselisihan di Pengadilan Tata Usaha Negara antara PT Asuransi Jiwa Bumi Asih Jaya dengan Otoritas Jasa Keuangan, padahal sudah terbukti secara konkrit jika Tcrmohon Pailit belum melunasi kIaim mnfaat asuransii kepada para pemegang polisnya dan memiliki utang terhadap Bank Tabungan Negara, Tbk. melalui PT Binasentra Purna. Berdasarkan uraian yang telah dikemukakan tersebut, maka Penulis merasa tertarik untuk mengkaji mengenai topik atau kasus tersebut secara komprehensif dan menuangkannya 
dalam bentuk proposal skripsi yang berjudul "Penerapan Pembuktian

Sederhana dalam Kepailitan Menurut UndangUndang No37 Tahun2004

Tentang Kepailitan dan PKPU (Studi Kasus: Putusan Nomor: 04/PDT.SUS.PAILIT/2015/PN.NIAGA.JKT.PST)"”

\section{A. Perumusan Masalah}

Skripsi inii akan membahas satu rumusan masalah yaitu bagaiimana hakiim mengaplikasikan pembuktiian sederihana pada perkara kepailitan sesuai dengan huikum kepailitan dalam Putusan Pengadilan Nomor 04/Pdt/Sus.Pailit/2015/PN.Niaga.JKT.PST?

\section{B. Metode Penelitian}

Penelitian hukuman adalah satu kegiatan guna mendapatkan peraturan huikum, prinsiip-priinsip huikum, ataupun doktrindoktrin huikum untuk memberi jawaban atas permasalahan huikum yaang ada. ${ }^{7}$ Berdasarkan judul yang diangkat oleh Penulis, maka metode penelitian yang akan digunakan Penulis adalah:

1. Tiipe Penelitian

Meitode penelitian ynang dipakai daIam skripsi inii adalah methode penelitian Hukum Norrnatif. Menurut Peter Mahmud Marzuki, penelitian hukum ini ialah satu cara guna menentukan satu peraturan huikum, asasasas huikum, ataupun doktrindoktrin huikum guna memberi jawaban atas isu huikum yanng ada ${ }^{8}$.

2. Jenis dan Surnber Penelitian Hukum

Pada skripsi inii, Penulis memakai jenis bahhan sekunder. Ini diperoleh dari telaah kepustakaan dan literatur, guna memperoleh jawaban

${ }^{7}$ Peter Mahmud Marzuki, Penelitian Hukum Edisi Revisi, Cetakan ke-8 (Jakarta: Kencana Prenada Media Group, 2013), hal. 35.

8 Ibid., hal. 34. 
atas permasalahan huikum serta menyajikan pula preskriipsi tentang yanng sebaiknya, dibutuhkan sumbersumber penelitian. ${ }^{9}$

Pengamatan yang dilakukan berdasarkan bahan sekunder di mana datadata ini berasal dari bahan-bahan sebagai berikut:

a. Bahhan huikum priimer, yaitu yanng mengiikat. Dan terdiri dari peraturan perundang-undangan, yaitu:

1. Kiitab UndangUndang Huikum Pcrdata

2. UndangUndang Nomor37 Tahun2004 tenttang Kepailitan dan Penundaaan Kewajiiban Pembayarran Uttang

3. UndangUndang Nomor 40 Tahun 2014 tenttang Perasuransiian b. Bahhan huikum sckunder, yaitu bahanbahan yanng memberikan penjelasan mengenai bahhan huikum priimer serta bisa membanttu menganalisa, memahami, serta menjelaskan bahhan huikum priimer, antara lain: teorii dan opini para lulusan, hasiI karrya oleh kaIangan huikum, penelusuran internet, tulisan iImiah, jurnaI, majaIah, koran, makaIah, danlain-lain.

c. Bahhan nonhukum, yaitu bahanbahan penunjang dari bahan hukum sekunder dan memberikan informasi tambahan bagi penelitian ini seperti Kamus Besar Bahasa Indonesia (KBBI) dan ensiklopedia serta petunjuk tambahan berupa wawancara dengan narasumber yakni Bapak Munir Fuady SH.,MH.,LL.M selaku Ahli Hukum Kepailitan,Praktisi dan juga seorang kurator.

3. Pendekattan

Dalam penelitian hukum ada bberapa macam pendekattan. Penulis akan mendapat pengetahuan yang berasal dariimacam-macam faktor

\footnotetext{
${ }^{9}$ Ibid., hal. 181.
} 
tentang permasalahan yangg sedang dicarikan solusinya. Terdapat 5 (lima) macam pendekatan, yaitu: ${ }^{10}$

1) Pendekattan UndangUndang (statute appproach)

2) Pendekattan kasuss (case appproach);

3) Pendekattan historiis (historical appproach);

4) Pendekattan komparatiif (comparative appproach);

5) Pendekattan konseptuaI (conceptual appproach).

Penulis menggunakan metode pendekattan undangundang (statue appproach) serta pendekattan konseptuaI (conceptual appproach). Pendekattan undangundang (statue appproach) dilaksanakan dengaan membedah seluruh undangundang serta seuruh regulasii yangg saling berkaitan kepada permasalahan huikum yangg sedanng dilakukan penanganan. Pendekattan konseptuaI berangkat darii pandanganpandangan serta doktriin- doktriin yangg bertambah luas dii daIam iImu huikum.

4. Tekniik PengumpuIan Bahhan Huikum

Tekniik pengumpuIan bahhan huikum bertujuan agar mendapatkan bahhan huikum di dalam peneliitian. Tekniik pengumpuIan bahhan huikum yangg meindukung serta bersangkutan kepada paparan peneilitian inii ialah pembelajaran dokumen atau yang disebut juga dengan studi kepusttakaan. Studii dokumern ialah satu cara untuk mengumpulkan bahhan huikum yangg dilaksanakan melaIui bahhan tertuIis dengarn menggunakan contentanalysis. ${ }^{11}$

5. Teknik Pengelolaan Bahhan Huikum

Tekniik pengelolaan bahhan huikum yangg Penuliis gunakan ialah pengelolaan secara runtut dan sistematis sehingga memudahkan penulis melakukan analisis. Pengelolaan bahan hukum dilakukan secara

\footnotetext{
${ }^{10}$ Ibid., hal. 93.

${ }^{11}$ Ibid., hal. 21.
} 
sistematis bertujuan untuk mendapatkan gambaran umum dari hasil penelitian.

6. Tekniik Analisiss Bahhan Huikum

Tekniik analisiss bahhan huikum yangg digunakan Penulis pada penelitian ini ialah dengan menggunakan methode analisis bahan hukum kualitatif, methode penelitian yangg menghasilkan deskriptiif analitiis yangg berasal dengan cara tertuIis, supaya datadata tersebut bisa ditelitti serta dipelajarii guna menganalisa objek peneIitian utuhdengan komprehensif serta mendaIam, maka di akhiirnya dapatt sepenuhnya memahami faktor-faktor yangg menjadii objekk peneIitian. ${ }^{12}$

\section{PEMBAHASAN}

\section{A. Hasil Penelitian}

Pailit merupakan asal kata kepailitan, yang diaplikasikan dari bahasa Belanda, yaitu failiet. Kata failiet sendirii berasall dari bahiasa Peranciis, yaituu faailiet yaing artinyai adaalah pemogokani ataui kemacietan pembayaran. Maka dari itu, katai pailiit dialam Bahasai Indonesiaa dapati didefiinisikan sebagai adianya suiatu keadaani tidak membayari lagi.

Pasall 1 Aingka 1 Undang-Undaang Nomori 37 Tahuin 2004 tentangi Kepailiitan dani Penundaain Kewajiiban Pembayarani Utangi menyatakani bahwai kepailitani adalahi suatui sitai umumi atasi seluruhi aseti kekayaani debituri pailiit yangi pengurusani dani pemberesannyai dilakukani olehi curatoir dii dalami ipengawasan hakiim pengawais sepertii diiatur dalami Undang-Undaang inii.

Kepailitan adalah sebuah jalan keluar atau solusi yang sifatnya umum untuk keluar dari permasalahan utang piutang dalam situasi seseorang debitur terhimpit dan sudah tidak bisa lagi untuk membayar utang-utangnya kepada

\footnotetext{
${ }^{12}$ Ibid., hal. 109.
} 
para krediturnya. Jika ketidakbisaan untuk membayar kewajiban utang yang telah jatuh tempo dan bisa ditagih sudah disadari oleh debitur, maka cara untuk mengajukan permohonan pernyataan pailit atas dirinya adalah dimungkinkan oleh suatu pengadilan. Kepailitan merupakan pelaksanaan lanjutan dari prinsip paritas creditorium dan prinsip pari passus pro rata parte dalam prinsip hukum harta kekayaan. Prinsip paritas creditorium artinya semua aset debitur baik berupa barang bergerak atau barang tak bergerak maupun aset yang sudah dimiliki debitur di waktu tersebut dan barang-barang yang akan dimiliki oleh debitur di masa depan terikat kepada penyelesaian kewajiban debitur. Sedangkan prinsip pari passu pro rata parte menyatakan jika aset kekayaan adalah jaminan bersama dengan hasil yang dibagikan secara adil kepada para kreditur, kecuali undang-undang menyatakan adanya kreditur yang wajib didahulukan untuk menerima pembayaran tagihan ${ }^{13}$

Padaa taanggal 18 Feebruari 2015, OJK mengajukani permohonani pernyataain paiilit ataas PT Asuransii Jiwaa Bumii Asihi Jayai dii Pengadilani Niagat padat Pengadilani Negerii Jakartia Pusait. Yangi menjadii sebabi pengajuani permohonani pernyataani pailiit tersebuti ialah karena PT Aasuransi Jiiwa Buumi Asihi Jayai telah tidaki melakukani kewajibannyai yangi diaturi dalami peraturani perundang-undangani di areai perasuransiani dengani tidaki memenuhii tingkaat solvabilitasi sedikiitnya $120 \%$ dani mempunyaii duai ataui lebihi krediitur daan tiidak membayari lunasi palingi sedikiit satui utangi yangi sudahi jatuhi tempoi dalami hali inii kredituri adalahi parai pemeganig poliis asuransii PT Asuransii Jiwa Bumii Asiih Jayai dani utangi kepadai PT Bankk Taabungan Negaraa, Tbk meelalui PT Biinasentra Purnai. Majeliis Hakiim yangi memeriiksa dan mengadilii permohonan pernyataan paiilit darii OJK terrhadap PT Asuransii Jiiwa Bumii Asiih Jayua dalami perkaria dengani Nomuor Regiister: 04/Pdt.Snus-Paiilit/2015/PN.Niiaga.Jkt.Pst menyatakan

\footnotetext{
${ }^{13}$ Adrian Sutedi, Hukum Kepailitan, (Bogor: Ghalia Indonesia, 2009), hal. 168.
} 
penolakan permohionan pailiit darii OJK terhadap PT Asuransi Jiwa Bumi Asih Jaya.

Menurut Hemat Penulis, Putusan Pengadilan Niaga Nomor: 04/PDT.SUS.PAILIT/2015/PN.NIAGA/JKT.PST merupakan putusan yang tidak benar menurut hukum karena tidak benar dalam mengaplikasikan pembuktian sederhana sesuai dengan yang diatur dalam Undang-Undang Nomor 37 Tahun 2004 tentang Kepailitan dan PKPU. Ini disebabkan oleh pendapat Majelis Hakim yaitu masih adanya pertentangan terhadap Keputusan Dewan Komisioner Otoritas Jasa Keuangan Nomor: KEP-112/D.05/2013 Tentang Pencabutan Izin Usaha di Bidang Asuransi Jiwa atas PT Asuransi Jiwa Bumi Asih Jaya maka pembuktian tentang klaim asuransi dalam perkara ini menjadi tidak sederhana.

\section{B. Analisis}

Pada tangigal 18 Februari 2015, OJK mengajukan piermohonan pernyataan pailit atas PTi Asuransi Jiwa Biumi Asih Jaya di Pengadiilan Niaga pada Pengadilan Niegeri Jaikarta Pusat. Yang menjadi sebiab ipengajuan permohonan pernyataan piailiit tersebut ialiah karena PT Asurainsi Jiiwa Bumi Asih Jaya telah tidak melakiiukan kewajibainnya yang diatur dailami peraturan perundang-undangan dii areia perasuransiani dengan tidak memienuihi tingkat solvabilitas sedikitnya 1i20\% dan mempunyaii dua atau lebihi kredituri dan tidak membayar lunas palinig sedikit satu utang yaing sudaih jatuh tempo dialam hal ini kreditur adalah paira pemegang polis asurainsi PTi Asuransi Jiwa Biumi Asih Jaya dan utang keipada PT Bank Tabungan Neigaria, Tbk melalui PTi Binasentra Purna. Majelis iHakim yang memeriksa dian miengadili perimohonan pernyataan pailit dari OJiK terhadap PT Asuranisi Jiwa iBumi Asiih Jaya dalam perkara dengan Nomori Register:i 04/Pdt.SusPailiit/20i15/PN.Niaga.Jkt.Pst menyatakian ipenolaikan permohoinan pailit dari OJKi terhadiap PT Asuransii Jiwia Bumii Asihi Jayia. 
iMienurut Hemat Penulis,suatu Putiusan Penigadilan Niaga Nomor: 04/PDiT.iSUS.PAILIT/2015/PN.NIAGA/JiKT.PST imerupakan putusan yang sangat tidak ibeinar meniurut hukum karena tiidak benair dalam mengaplikasikan pembuktiiani sederhana sesuai dengan iyang diatur dalam Undang-Undang Nomor $3 i 7$ Tiahun 2004 tentang Kepailiitan dan PKPU. Ini disebabkan oleh pendapat iMaijelis Hakim yaitu masih adianya pertentangan terhadap Keputusan Dewan Kiiomisioner Otoritas Jasa Kieuangan Nomor: KEP-112/D.05/2013 Tentang Pieincabutan Izin Usaha di Biidang Asuransi Jiwa atas PT Asuransi Jiwa Bumii iAsih Jaya maka pembuktiani tentang klaim asuransi dalam perkiara ini menijadii tidak sederhana. Sebelum menguraikan tentang dasar argumientasi Peniulis terkiait dengan jawaban Peinulis atas rumusan masaliah di atas, Penuilis terlebih dului akan menjelaskan daisar pertimbangan hakim

Di bawaih ini merupakan dasiar-dasar penolakan permohonan pailit hakim Pengadilan Niiaiga pada pengadilain Negeri Jakarta Pusat pada perkara ini:

Dalam peirtiimbangannya, Tiermohon sebagai Perusahaan Asuransi Jiwa berdasarkan buikiti P-7,P-8,P-9 diiketahui bahwa dari hasil analisis atas laporan keuangan Triwuilian II tahun $200 i 7$ yang dilakukan oleh Kementrian Keuangan, Termohion mengialami penurunan tingkat solvabilitas di tahun 2007 menjadi sebesar 74i,14\% dimana sudiah disampaikan dengan surat nomor S1287/MK.10/200i7 tianggal 9 Okitober 2007 tentang sanksi peringatan pertama, Surat Nomori S-1i468/MK.10/2i007 tanggal 4 Desember 2007 tentang Sanksi Peringatan Keiduai. Surat Noimor S-804/MK.10/2008 tanggal 4 Juni 2008 tentang Sanksi Pieriingatan Keitiga. Sesuai dengan bukti bertanda P-10 diketahui terhadap pieriingatan tersebut Termohon tetap tidak mampu memenuhi tingkat solviabiilitas seperti diharuskain ketentuan Pasal 2 ayat (1) dan Pasal 43 ayat (2)i hiuruf c KMK Nomor: 42ii4 Tahun 2003 dengan perubahannya, sehinggiai Kementrian Keuangan mengeluarkan sanksi 
pembatasan kegiatan usaihai dengan surat Nomor S-694/MK.10i/2009 tanggal 30 April 2009. Selain saniksii-sanksi tersebut di atas sesuai dengian bukti P-12 diketahui Kementrian Keuianigan juga mengeluarkan sanksi kepada Termohon yaitu: Sanksi mengenai kiiekiurangan dana jaminan dengan surat Nomor: S87/MK.10/2010 tanggal 1 iFiebruari 2010 tanggal 1 Februari 2010, tentang sanksi pembatasan kegiatani iusaha dengan surat Nomor: S-846/MK.10/2011, tanggal 1 Agustus 2011; sesiuiai dengan bukti P-13 Laporan Hasil Pemeriksaan terhadap Termohon yang diliaiikukan oleh Pemohon tanggal 9 Desember 2013, terbukti jika perhitungan peribandingan tingkat solvabilitas Termohon untuk jangka waktu laporan 31 Deiseimber 2012 sejumlah minus 1.159,70\% atau mengalami kekurangan sejumilaih Rp1.094.163.000,- (satu triliun sembilan puluh empat miliar seratus enami piuluh tiga juta rupiah) sesuai dengan Laporan hasil Pemeriksaan tersebut dii iatas, perhitungan perbandingan tingkat solvabilitas Termohon untuk peiriode liaporan 30 juni 2013 sejumlah minus 1.045,62\%, atau mengalami keikurangian sejumlah Rp1.020.752.000,- (satu triliun dua puluh miliar tujuh ratius limai puluh dua juta rupiah), sesuai dengan bukti P-14 laporan keuangan Terimohon per 31 Mei 2013 yang disiusun sesuai dengan KMK Nomor: 424 tahuni 2003 dan perubahannya pada keinyataannya total ekuitas Termohon sebesari minus Rp953,54 miliar; walauipun sudah diberikan sanksi-sanksi tersebut idi atas, Termohon tetap tidak maimpu untuk memenuhi tingkat solvabilitas dian ekuitas yang diharuskan, sehiingga OJK mencabut izin usaha Termohon diengan keputusan dewan komisionier Otoritas Jasa Keuangan Nomor: KEP-112/iD.05/2013 tanggal 18 Oktober 20113 tentang Pencabutan Izin Usaha di Bidang iAsuransi Jiwa atas PT Asuransi iJiwa Bumi Asih Jaya (bukti P-3), yang bertujiuan untuk menjaga kepentingani pemegang polis dan masyarakat dan untuk meingantisipasi kerugian masyarakait yang akan muncul di hari yang akan datang isebagai akibat pelanggarani akan peraturan perundang-undangan di area Perasuiransian. Menimbang, bahwa 
bukti pertanda P-3 (sama dengan bukti T-3) dikeitahui bahwa Pemohon sudah menerbitkan Keputusan Dewan Komisioner Oitoritas Jasa Keuangan Nomor: KEP-112/D.05/2013 tanggal 18 Oktober i2013 Tentang Pencabutan Izin iUsaha di Bidang Asuransi Jiwa atas PT Asurainsi Jiwa Bumi Asih Jaya; dengan ialasan karena Termohon sudah tidak menitaati peraturan perundang-undangan idi bidang usaha perasuransian.i

iMajelis Hakim berpendiapat masih terdapat pertentangan akan Keputusan Dewian Komisioner Otoritais Jasa Keuangan Nomor: KEP-112/D.05/2013 Tentaing Pencabutan Izin Usaiha di Bidang Asuransi Jiwa atas PTi Asuransi Jiwa Bumi Asih Jaya. Sesuai deingan bukti bertanda P-3 (sama degain bukti T3) diketahui bahwa Pemohon telaih menerbitkan Keputusan Dewan Kiomisioner Otoritas Jasa Keuangan Nomor: KiEP-112/D.05/2013 tanggal 18 Oiktober 2013 Tentang Pencabutan Izin Usaha di iBidang Asuransi Jiwa atas PTi Asuransi Jiwa Bumi Asih Jaya; dengan alaisan karena Termohon telah melianggar peraturan perundang-undangan di biidang usaha perasuransian. Berdasarkan penjelasan tersebut dapat ditarik keisimpulan bahwa munculinya Keputusan Dewan Komisioner Otoritas Jasa iKeuangan Nomor: KEP112/D.05/2013 tanggal 18 Oktober 2013 Tentang Pencabutan Izin Usahai di Bidang Asuransi Jiwa atas PT Asuransi Jiwa Bumi Asiih Jaya; disebabkian Termohon tidak dapat memenuhi tingkat solvabilitas palinig sedikit 120i\% (seratus dua puluh per seratus) dari resiko kerugian yang kiemungkinan timbiul sebagai akibat dari deviasi dalam pengelolaan kekayaan dain kewajiban, bahkain mengalami ekuitas minus Rp931,65 miliar yang melakuikan pelangigaran terhadap Peraturan Pemerintah Nomor 81 Tahun 2008; hal miana adalahi merupiakan sailah satu dasar keberadaan utang Pemohon dalam miengajukan Permohonan Pernyataan Pailit terhadap Termohoin; sementara itu terhiadap dalil adanya utang tersebut telah dibantah termohoin dan termohon menyaitakan masih dapat melakukan kewajibannnya yang adailah pembayaran 
klaiim terhadap para pemegang polis; selain itu sesuai dengain dalil jawaban Termiohon yang sesuai dengan bukti bertanda T-4 berupia salinan Akta Perimohonan Kasasi 180/G/2013/PTUN-JKT yang tidak idisanggah oleh Pemohoin diketahui bahwa Keputusan Dewan Komisioneir Otoritas Jasa Keuangain Nomor: KEP-112/D.05/2013 tanggal 18 Oktobeiir 2013 Tentang Pencabuitan Izin Usaha di Bidang Asuransi Jiwa atas PT Asuiransi Jiwa Bumi Asih iJaya, telah tidak diterima oleh Termohon dan telah dilaiksanakan upaya hukium yang saat ini masih dalam proses pemeriksaan kasasi isehingga belum memperoleh kekuatan hukum tetap ;berdasarkan uraian pertimibangan tersebut diaits Majelis Hakim berpendapat bahwa pembuktian klaim iasuransi dalam perkarai ini menjadi tidak sederhana; seperti dalam pasal 8 ayiat (4) UndangUndang iNomor 37 Tahun 2004 tentang kepailitan dan PKPU, idan karenanya dinyatakian untuk ditolak; Mengingat ketentuan Pasal 2 ayat (1i), pasal 8 ayat (4) Undaing-Undang No.37 Tahun 2004 tentang Kepailitan dian Penundaan Kewajiban Piembayaran Utang, serta perundang-undangain lain yang bersangkutani

Beridasarkan uraian dasar-dasari pertimbangan hakim tersebut di atas, penuliiis menilai hakim Pengadilan Niaiga Jakarta Pusat telah tidak tepat dalam meneraiipikan pembuktian sederhana sepierti diatur dalam Undang-Undang Nomor 37 Tahuini 2004 tentang Kepaiilitan dan Penundaan Kewajiban Pembayaran Utang sehinigga menghasilkani putusan yang tidaki tepat sesuai dengan hukum. Adapun yang meniijadi dasair argumen penulis aidalah sebagai berikut:i

1. Majeliis Hakiim dalam menilai bahwa PT Asuransi Jiwa Bumi Asiiih Jaya masih mampu iiuntuk melaksanakan kewajibannya telah salah karenia pada faktanya secara nyiata-nyata termohon telah gagal dalam melunasi utanig klaim polis, sehingga ibena-benar tidak mempunyai kemampuan untuk melaksianakan kewajibanniya yaitu melunasi klaim kepada seluruh pemegang polis;i 
2. Majelis Hakiim dalam menyatakan bahwa permohonan pernyatiaan pailit ditolak karenia masih terdapat usaha hukum kasasi dalam perkara itata usaha negara terhadaip Keputusan Dewan Komisioner Otoritas Jasa Keuangian Nomor Kep-112/D.05/i2013 Tanggal 18 Oktober 2013. Keputusan Dewian Komisioner Otoritas Jasa Kieuangan Noimor KEP-112/D.05/2013 tentaing Pencabutan Ijin Usaha di Bidanig Asuransii Jiwa atas PT Asuransi Jiwa Buimi Asih Jaya telah salah, karena Kieputusan Tiata Usaha Negara yang diterbitkian oleh Dewan Komisioner Otoiritas Jasa Kieuangan sesuai idengan hak yaing diberikan berdasarkan peraituran perundang-undangani yang berlakiu; pencabutan izin usaha PT Asuranisi Jiwai Bumi Asih Jiaya adalah sanksi hukuim yang harus diterima oleh PT iAsurainsi Jiwa Bumi Asiih Jaya) sebagai dampiak dari tidak dapat terpenuhinyai tingikat solvabilitas siedikitnya $120 \%$ (seratus diua puluh per seratus) dari resikioi kerugian yang mungkin muncul sebagai diampak dari deviasi dalam menigeloila kekayaan dain kewajiban.

3. Bierdasairkan Paisali 2 ayiat (1) UU iKepailitian menyiatakan: "Debituir yiang mempunyaii idua aitiau lebihi Krediitur idan tiidak membaiyar lunias sediikitnya siatu utanig iyaing itelah jatuih waiiktu dan dapat ditagih,dinyatakan pailit dengan putusan Piengadilan, baik atas ipermohonannya sendiri maupun atas permohonan satui atau lebih kredituirnya."; Termohon mempunyai kewajiban untuk memiberikan pembayarani sebagai akibat meninggalnya tertanggung/pemegang piolis atau pembayarain yang didasarkan pada jatuh tempo polis tertanggunig dengan manfaat iyang telah ditetapkan dalam perjanjian; dengan demikiian, pada saat timbulniya kewajiban Termohon untuk memberikan penggantiani kepada para tertaniggung/pemegang polis sesuai perjanjian, maka Termohion mempunyai utangi yang jatuh tempo dan dapat ditagih; adapun sejumlahi pemegang polis yaing telah mengajukan klaim manfaat asuransi kepada Teirmohon dengan total iklaim yang harus dibayar oleh Termohon sebesar Rp831.12i7.649,00 (delapani ratus tiga puluh satu juta 
seratus dua puluh tujuh ribu einam ratus empat puluhsembilan rupiah) selain pemegang Termohon memilikii utang klaim laiinnya. Berdasarkan surat Termohon kepada PT. Binasentria Purna Nomor 10i1/Dirkein/2012 tanggal 15 Juni 2012 perihal Nilai Tunai idan Cara Pembayiaran (bukti P-16A), yang selanjutnya disampaikan oleh PT.i Binasentra Purnai kepada OJK melalui surat Nomor 006/DIR/I/2013 tanggal 1i1 Januari 2013 peirihal pengalihan portofolio asuransi jiwa kredit KPR-BTN (biukti P-16B) antaria lain menyebutkan bahwa Termohon hanya dapat menyanggiupi untuk melakiukan pengalihan portofolio sebesar Rp30.000.000.000,00 (tigai puluh miliar ruipiah) dari nilai tunai premi seharusnya yang berdasarkan hasil iperhitungan aktiuaria yang telah disepakati sebagai dasar data dalam pengalihian portofolio iasuransi jiwa kredit yaitu sebesar Rp78.583.449.492,00 (tujuhi puluh delapani miliar lima ratus delapan puluh tiga juta empat ratus empat piuluh sembilan iribu empat ratus sembilan puluh dua rupiah) posisi sampai dengan $\mathrm{i}$

bulan Desember 2012.Degan demikiain tierbukti Termohon memilik utang yang telah jatuh tempo kepada PT. Bank Taiibungan Negara

(Persero), Tbk melalui PT. Binasentra iPurnai;

4. Majelis Hakim telah salah meneraipkani hukum yang berlaku Karena Menganggap pembuktian mengenai klaiimi Asuransi Dalam Perkara Ini Menjadi Tidak Sederhana karena pertimbaingian dari pendapat termohon yang berpendapat bahwa klaim asuransi adalahi buikan utang dan pemegang polis bukanlah Kreditur, sebagaimana Pasal 1 aingkia 1 Undang-Undang Nomor 40 Tahun 2014 Tentang Perasuransian sehingiga iTermohon tidak memilik utang terhadap pemegang polis yang sudah jatuih tiempo dan dapat ditagih,; serta Termohon masih memiliki kemampuan untiuk imelakukan kewajibannya yaitu pembayaran klaim kepada para pemegang pioliis. berdasarkan Pasal 1 angka 6 Undang-Undang Nomor 37 tahun 2004 teintaing Kepailitan dan Penundaan Kewajiban Pembayaran Utang, dinyatakan:i "iUtang adalah kewajiban yang 
dinyatakan atau dapat dinyatakan dalam jumilaih uang baik dalam mata uang Indonesia maupun mata uang asing, baik seciaria langsung maupun yang akan timbul di kemudian hari atau kontinjen, yanig itimbul karena perjanjian atau undang-undang dan yang wajib dipenuhi olehi Diebitur dan bila tidak dipenuhi memberi hak kepada Kreditur untuk mendiapiat pemenuhannya dari harta kekayaan Debitur"; berdasarkan peraturan periunidang-undangan tersebut sudah sangat jelas klaim asuransi yang telah jaituh tiempo adalah merupakan utang;Berdasarkan hasil wawancara dengan Biapak Miunir Fuady, beliau juga berpendapat bahwa klaim asuransi yang tiidak diibayarkan sudah jelas merupakan utang karena klaim asuransi meriupakani kewajiban yang harus dibayarkan, dapat dinilai dengan uang dan timbiul dari siuatu perjanjian

5. Majelis Hakim dalam menerapkan ketentuan Paisal 8 Ayiat (4) UndangUndang Nomor 37 Tahun 2004 Tentang Kepailitani Dan Penuindaan kewajiban Pembayaran Utang telah salah. Pasal 8 ayat (i4) Undang-Unidang Nomor 37 Tahun 2004 tentang Kepailitan dan Penundaan iKewajiban Peimbayaran Utang menyatakan bahwa: "Permohonan pernyataan piailit harus dikiabulkan apabila terdapat fakta atau keadaan yang terbukti secarai sederhana baihwa persyaratan untuk dinyatakan pailit sebagaimana dimaksud idalam Pasal i2 ayat (1) telah dipenuhi. penjelasan Pasal 8 ayat (4) Undang-Unidang Nomori 37 Tahun 2004 tentang Kepailitan dan Penundaan Kewajiban Peimbayaran Utiang menyatakan bahwa: "Yang Dimaksud dengan "fakta atau kieadaan yangi terbukti secara sederhana" adalah adanya fakta dua atau lebih kireditur dan fiakta utang yang telah jatuh waktu dan tidak dibayar. Sedangkani perbedaan besarnya jumlah utang yang didalihkan oleh Pemohon Pailit idan Termohon Pailit tidak menghalangi dijatuhkannya putusan pernyataan piailit"; Majelis Hakim dalam pertimbangan nya hanya menyimpulkan:i

a. Alasan terbitnya Keputusan iDewan Komisioner Otoritas Jasa Keuangan Nomor KEP-112/D.0i5/2013 tanggal 18 Oktober 2013 
tentang Pencabutan Ijin Usaha dii Bidang Asuransi Jiwa atas PT. Asuransi Jiwa Bumi Asih Jaya diikarenakan Termohon tidak dapat memenuhi tingkat solvabilitas palinig sedikit $120 \%$ bahkan Termohon Kasasi mengalami ekuitas minus Rip931,65 milyar yang melanggar Peraturan Pemerintah Nomor 81 Tahiun 2008.

b. Termohon telah melakukan upayai hukum kasasi atas penerbitan Keputusan Dewan Komisioner Otoriitas Jasa Keuangan Nomor KEP112/D.05/2013 tanggal 18 Oktober i2013 berdasarkan fotocopi Akta Permohonan Kasasi Nomor 180/G/i2013/PTUN-JKT., yang saat ini masih dalam proses pemeriksaan ikasasi sehingga Majelis Hakim beranggapan masih ada perselisihian terhadap Keputusan Dewan Komisioner Otoritas Jasa Keuangian Nomor KEP-112/D.05/2013 tanggal 18 Oktober 2013;i

c. Berdausarkan urauian peiurtimbangan terseubut di atuas Maujelis Hakim berpendaapat baiahwa pemubuktian meungenai klauim asuuransi dualam perkairaa iini menijadi tidiak sederhania sebagaimaina diamanaitkani Piasal 8 aiyat (4) Undiang-Uindang Nomior 37 Tahuin 2004 itentaing Kepaiilitan Dain Peinundaan Kewiajiban Pembaiyaran Utainig dain kairenanya dinyatakian untuki ditolaik;i i

Deingan demikian atas pertimbangan Majelis Hakim tersebut datas Majelis iHakim telah salah dalam menerapkan ketentuan Pasal 8 ayat (4) Undang-iUndang Nomor 37 Tahun 2004 tentang Kepailitan Dan Penundaan Kewajiban Pembayaran Utang;

Syarat pembuktian sederhana diatur dalam Pasal 8 ayat (4) yang menyatakan: "Permohonan pernyataan pailit harus dikabulkan apabila terdapat fakta atau keadaan yang terbukti secara sederhana bahwa 
persyaratan untuk dinyatakan pailit sebagaimana dimaksud dalam Pasal 2 ayat (1) telah dipenuhi”. Berdasarkan pasal tersebut dapat dikatakan bahwa pada dasarnya mengenai pembuktian sederhana tersebut mengacu kepada syarat-syarat yuridis yang ada pada Pasal 2 ayat (1) UUK, yaitu:

1. Adanya debitur yang tidak membayar utang

Debitur adalah orang yang mempunyai utang karena perjanjian atau undang-undang yang pelunasannya dapat ditagih di muka pengadilan. Dalam kasus ini, PT Asuransi Jiwa Bumi Asih Jaya adalah sebagai debitur, yang memiliki kewajiban membayar lunas klaim asuransi kepada para pemegang polis yang telah mengajukan klaim manfaat asuransi, dan PT Asuransi Jiwa Bumi Asih Jaya selaku perusahaan asuransi yang memiliki kewajiban untuk memenuhi tingkat solvabilitas paling sedikit $120 \%$.

2. Adanya lebih dari satu kreditur

Kreditur adalah orang yang mempunyai piutang karena perjanjian atau undang-undang yang dapat ditagih di muka pengadilan. Dalam kasus ini pemegang polis disebut sebagai kreditur, terdapat lebih dari satu kreditur, yaitu para pemegang klaim manfaat asuransi serta PT. Bank Tabungan Negara, Tbk.melalui PT Binasentra Purna.

3. Adanya lebih dari satu utang

Utang adalah kewajiban yang dinyatakan atau dapat dinyatakan dalam jumlah uang, baik dalam mata uang Indonesia maupun mata uang asing, baik secara langsung maupu yang akan timbul di kemudian hari atau kontinjen, yang timbul karena perjanjian atau undang-undang dan yang wajib dipenuhi oleh debitur, serta bila tidak dipenuhi memberi hak kepada kreditur untuk mendapat pemenuhannya dari harta kekayaan debitur. Dari pengertian di atas, maka diketahui utang dapat timbul dari suatu perjanjian atau undang-undang. Dalam kasus 
ini, utang timbul dari perjanjian asuransi antara PT Asuransi Jiwa Bumi Asih Jaya dan pemegang polis asuransi yang telah disepakati kedua belah pihak.

4. Minimal satu utang sudah jatuh tempo

Utiang yiang teliah jiatuh waktiu dani idapat diitagih adailah kewajibian uintuk membiayar uitang yaing itelah ijatuh wakitu, baiik kariena idiperjanjikan, kairena peircepatan waktiu ipenagihannya sebagaimania idiperjanjikan, ikarena pengienaan sankisii aitau deinda olehi iinstansi iyang beirwenang, maiupun kairena puitusan pengadiilan, arbiiter, ataiu majelis airbitrase.

Dailam kiasus iini, PiT Asuransi Jiwia Biumi Asiih Jiaya adailah perusaihaan asurainsi yaing itelah tidaik meliaksanakan kewajiiban sesuaii peratuiran peruindang-unidangan di ibidang periasuransian yang idapat diikategorikan isebagai iutang beirdasarkan keteintuan Pasali 2 iayat (1) dan Piasal 43i ayat (2) KMKi Nomor: 424i Tahun 2i003 besertia peirubahannya, yanig pada iintinya tiidak dapait miemenuhi tiingkat soilvabilitas palinig siedikit 120\% (seratus dua puluh per seratus) darii resikoi keriugian yaing mungkini tiimbul siebagai akiibat darii ideviasi dalim pengeliolaan kiekayaan dian kewajiiban, bahikan menigalami ekuiitasminus Rp931,6 miiliar yaing melainggar pieraturan piemerintah Nomior 81 taihun 2008 Pasal 6B ayat (1) huruf b.

5. Minimal satu utang sudah dapat ditagih

Utang yang dapat ditagih adalah utang yang lahir dari adanya perjanjian yang sah (memenuhi syarat sahnya perjanjian) dan/atau utang yang lahir karena undang-undang (contohnya pajak).

Syarat sahnya perjanjian apabila dikaitkan dengan kasus ini adalah: 
a. Sepakat mereka yang mengikatkan dirinya

Dalam kasus ini, para pihak yakni PT Asuransi Jiwa Bumi Asih Jaya dan pemegang polis telah sepakat mengenai isi perjanjian, karena perjanjian tersebut dibuat oleh kedua belah pihak.

b. Cakap untuk membuat suatu perjanjian

Dalam kasus ini kedua pihak, baik PT Asuransi Bumi Asih Jaya dan pemegang polis, dikatakan cakap berbuat hukum, karena PT Asuransi Bumi Asih Jaya merupakan badan hukum yang sah menurut Undang-Undang Nomor 40 Tahun 2007 tentang Perseroan Terbatas.

c. Mengenai suatu hal tertentu

Dalam kasus ini, ditunjukkan bahwa perjanjian mengenai asuransi jiwa.

d. Suatu sebab yang halal

Asuransi yang menjadi objek dalam perjanjian tersebut tidak bertentangan dengan ketentuan hukum.

Berdasarkan analisa di atas, apabila dikaitkan dengan kasus, maka perjanjian yang dibuat antara PT Asuransi Jiwa Bumi Asih Jaya dan para pemegang polis sudah memenuhi syarat sahnya perjanjian. Dengan demikian, dapat dikatakan utang yang timbul berdasarkan perjanjian tersebut, merupakan utang yang dapat ditagih.

6. Permohonan pailit diajukan oleh pihak yang berwenang

Apabiila dikaiitkan dengain kasus inii, piihak yaing berhak meingajukan piermohonan paiilit adaliah Otoriitas Jiasa Kieuangan. Beirdasarkan Paisal 50 aiyat (1) Undangi-Undangi Nomori 40 Tahun 2014 tentangi Perasuransiian yaing meniyatakan "Peirmohonan perinyataan paiilit terhadaip perusiahaan asuransii, perusahaian 
asuransii syariiah, periusahaan reasuransii, atiau perusahaian reasuransii syariiah berdasairkan undiang-undiang iini hanyia dapati diajukain oleh Otoriitas Jaisa Keiuangan.

7. Pernyataan pailit diputus oleh Pengadilan Niaga

Dalam kasus iini, Majeliis Hiakim Peingadilan iNiaga Jaikarta Piusat paida tangigal 15 Apriil 2015 memutuskani untiuk menoilak permiohonan paiilit yiang diiajukan olieh Diewan Komiisioner Otoritias iJasa Keuaingan.

\section{PENUTUP}

\section{A. Kesimpulan}

Dari analisis yang telah dilakukan, Penulis dapat menarik kesimpulan bahwa alat-alat bukti yang diserahkan oleh pihak Otoritas Jasa Keuangan seharusnya sudah cukup bagi hakim untuk dapat menerapkan pembuktian sederhana karena pembuktian sederhana telah terpenuhi dan sesuai dengan Pasal 8 ayat (4) Jo Pasal 2 ayat (1) Undang-Undang Nomor 37 Tahun 2004 Tentang Kepailitan dan Penundaan Kewajiban Pembayaran Utang yaitu dimana telah terbukti terdapat fakta 2 (dua) kreditur dan setidaknya satu utang yang telah jatuh tempo dan dapat ditagih, sebagaimana dimaksud dalam persyaratan kepailitan. Karena persyaratan kepailitan sudah terpenuhi, maka seharusnya PT Asuransi Jiwa Bumi Asih Jaya dapat dinyatakan pailit.

\section{B. Saran}

Berdasarkan hasil penelitian yang telah dilakukan, penulis dapat menyampaikan beberapa saran terkait dengan permasalahan yang diangkat oleh penulis, yaitu:

1. Bagi Pemerintah Indonesia :

Sebaiknya pemerintah Indonesia lebih mengawasi penerapan Undang-Undang yang sudah dibuat agar dapat memberikan rasa keadilan bagi para pihak yang berperkara. 
2. Bagi Hakim Pengadilan Niaga di Indonesia:

Diharapkan kepada para Hakim Pengadilan Niaga di Indonesia untuk seyogyanya lebih biijaksana daliam memeriiksa dani mengadiili suatui perkaira yangi diihadapkan kepaidanya, terlebiih lagii suatu perkara paiilit yanig dampakniya sangiat luair biiasa.

\section{Bagi Masyarakat Indonesia:}

Sebaiknya masyarakat Indonesia khususnya kepada para kreditur dan debitur untuk lebih memperhatikan dan mentaati Hukum Kepailitan yang berlaku di Indonesia, karena dari hukum tersebut kreditur dan debitur dapat mendapatkan perlindungan atas haknya.

\section{DAFTAR PUSTAKA}

\section{A. Buku}

Algra, N. E. Inleiding tot Het Nederlands Privaatrecht. (Groningen: Tjeenk Willink, 1974).

Asikin Z. Hukum Kepailitan dan Penundaan Pembayaran di Indonesia. (Surabaya: Bina Ilmu, 1990).

Marzuki,Peter Mahmud. Penelitian Hukum Edisi Revisi. Cetakan ke-8. (Jakarta: Kencana Prenada Media Group, 2013).

Sutantio, R., Oeripkartawinata, I. Hukum Acara Perdata Dalam Teori dan Praktek. (Bandung: Mandar Maju, 2009).

Sutedi A. Hukum Kepailitan. (Bogor: Ghalia Indonesia, 2009).

Suyudi A. Eryanto, Nurbayanti H. D., Kepailitan di Negeri Pailit. (Jakarta: Pusat Studi Hukum dan Kebijakan Indonesia, 2004).

\section{B. Peraturan Perundang-undangan}

Indonesia, Undang-Undang Nomor 37 Tahun 2004 tentang Kepailitan dan Penundaan Kewajiban Pembayaran Utang. 
Indonesia Undang-Undang Nomor 40 Tahun 2014 tentang Perasuransian

(Lembaran Negara Republik Indonesia) 